\title{
Hélisenne de Crenne, Le Songe de madame Helisenne
}

\section{Michele Mastroianni}

\section{(2) OpenEdition}

\section{Journals}

\section{Edizione digitale}

URL: http://journals.openedition.org/studifrancesi/9457

DOI: $10.4000 /$ studifrancesi.9457

ISSN: 2421-5856

\section{Editore}

Rosenberg \& Sellier

\section{Edizione cartacea}

Data di pubblicazione: 1 décembre 2007

Paginazione: 637

ISSN: 0039-2944

\section{Notizia bibliografica digitale}

Michele Mastroianni, «Hélisenne de Crenne, Le Songe de madame Helisenne», Studi Francesi [Online], 153 (LI | III) | 2007, online dal 30 novembre 2015, consultato il 10 janvier 2021. URL: http:// journals.openedition.org/studifrancesi/9457 ; DOI: https://doi.org/10.4000/studifrancesi.9457

Questo documento è stato generato automaticamente il 10 janvier 2021.

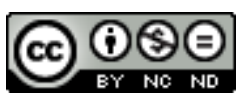

Studi Francesi è distribuita con Licenza Creative Commons Attribuzione - Non commerciale - Non opere derivate 4.0 Internazionale. 


\title{
Hélisenne de Crenne, Le Songe de madame Helisenne
}

\author{
Michele Mastroianni
}

\section{NOTIZIA}

HÉLISENNE DE CRENNE, Le Songe de madame Helisenne, édition établie et annotée par JeanPhilippe BEAUlieu et Diane DeSRosiers-bonin, Paris, Champion, 2007 ( «Textes de la Renaissance», 127), pp. 189.

1 Dopo le edizioni critiche delle Epistres familieres et invectives (Champion, 1996) e delle Angoysses douloureuses qui procedent d'amour (Champion, 1997) di Hélisenne de Crenne, è ora criticamente edito il Songe de madame Helisenne, terzo e ultimo scomparto di un trittico, e anche il meno studiato. Apparentemente meno innovatore quanto a genere letterario, nella misura in cui riprende la struttura medievale del somnium, il Songe affronta gli stessi problemi e tratta gli stessi materiali delle altre due opere, quelli concernenti il rapporto amoroso (e adultero) Amant/Dame. Nell'Introduzione i due editori ritracciano brevemente, ma chiaramente, la storia degli antecedenti letterari del Songe. La presente edizione critica si basa sull'editio priceps di Denis Janot (1540), di cui riproduce le incisioni, collazionata con le successive stampe del 1541, 1543,1551 e 1560. Il testo è accuratamente annotato e accompagnato da glossario. 